\title{
COMPARISON OF NOISE EXPOSURE LEVELS BETWEEN WORKPLACES
}

\author{
Alberto Behar, P.Eng., C.I.H. \\ Ontario Hydro, 757 McKay Road, Pickering, Ontario L1W 3C8
}

\section{Project Summary}

\subsection{Introduction}

As an essential part of any hearing conservation program, noise exposure levels of workers are measured to assess their risk of hearing loss. Whenever the legal limit is exceeded (e.g., $85 \mathrm{dBA}, 90 \mathrm{dBA}$, etc.), measures have to be done to eliminate or reduce the risk. To do so, work practices are re-examined, hearing protection is introduced and/or engineering controls are put in place to reduce noise levels, and consequently, noise exposure levels.

Any of the above measures requires use of resources, that are usually at a high demand and short supply.

This paper presents a process by which several indices are calculated using:

(a) the average noise exposures of the different work groups ( $\left.L_{\text {Trado }}\right)$ (e.g., 85$90 \mathrm{dBA}, 90-95 \mathrm{dBA}$, өtc.).

The indices calculated using this method can be used in isolation or combined, so that a more complete picture (more representatlve rating) be obtained.

\subsection{The Process}

\subsection{Ranges of Nolse Exposures}

The first step in the process is to choose ranges of noise exposures the data will divide. The first range usually has the lower limit of $85 \mathrm{dBA}$, since lower noise exposure levels do not present risk of hearing loss. Because in most cases $90 \mathrm{dBA}$ is the limit when engineering noise control are recommended, the first range can be $85-90 \mathrm{dBA}$. The next can be 90-95 dBA, etc.

\subsection{Collectlve Nolse Exposure}

The term "collectlve noise exposure" is defined as the sum of the products of the number of workers in each trade times their $\mathrm{L}_{\text {Trade. }}$. In other 'Nords, if there are two trades of 20 and 25 workers each and their $\mathrm{L}_{\text {Trade }}$ are 85 and $90 \mathrm{dBA}$ respectively, the collective noise exposure for that workplace will be:

$$
(20 \times 85)+(25 \times 90)=3950 \text { person } \times \text { dBA }
$$

\subsection{Average Nolse Exposure Level}

The average noise exposure level (ANEL) for each noise exposure range is calculated by dividing the sum of the collective noise exposures within each range by the number of workers within the same range. The ANEL represents roughly the average noise exposure of a worker within the noise exposure range.

\subsection{Normalized Average Nolse Exposure Level}

The normalized average nolse exposure level is obtained by subtracting $85 \mathrm{dBA}$ from the average nolse exposure level. This is done to enhance differences between noise exposure levels from the different workplaces: it is easier to "see" a difference between 2 and $5 \mathrm{~dB}$, than between 87 $(85+2)$ and $90(85+5) \mathrm{dB}$.

By subtracting 85 dBA (accepted as a "safe" limit), the normalized level can also be used as an estimate for the risk of hearing loss.

\subsection{Maximum Collectlve $L_{\text {Trade }}$}

Another estimate that can be used for interworkplaces comparison is the maximum collective $L_{\text {Trade }}$. This is the collective noise exposure for the trade with the highest $L_{\text {rade }}$ within each noise exposure range. 
NUMBER OF NOISE EXPOSED STAFF

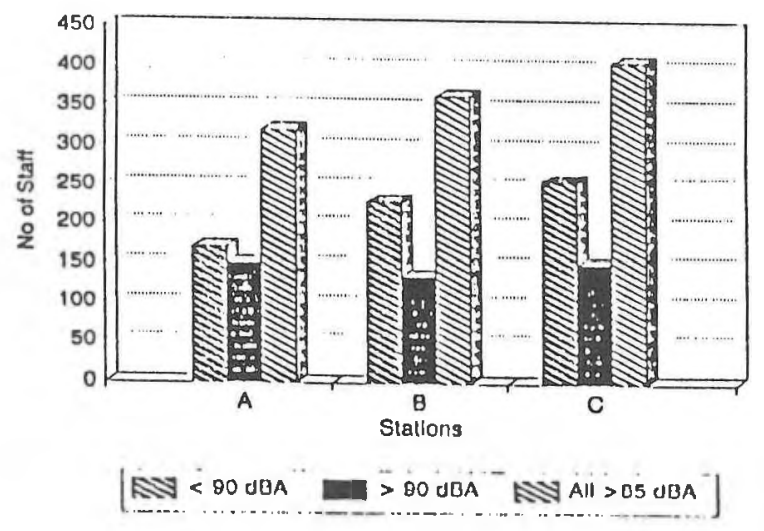

NORMALIZED NOISE EXPOSURES

(Coll Lirade/No of Stalf) / - 85 dBA

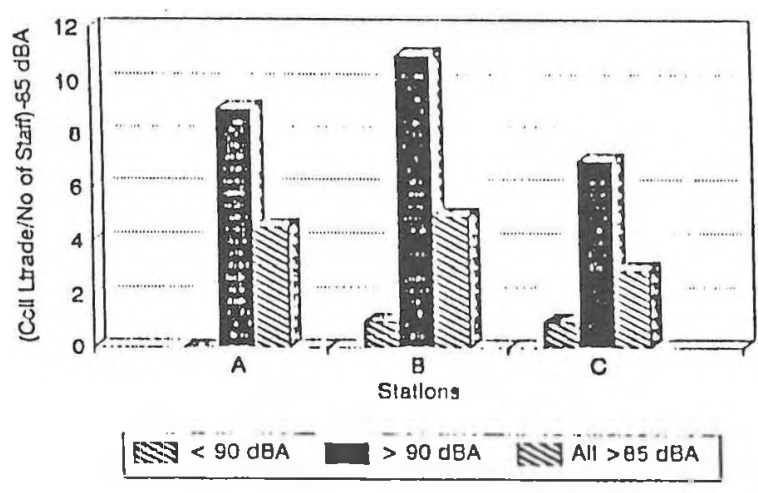

COLLECTIVE NOISE EXPOSURE LTrade $\times$ No of Staft

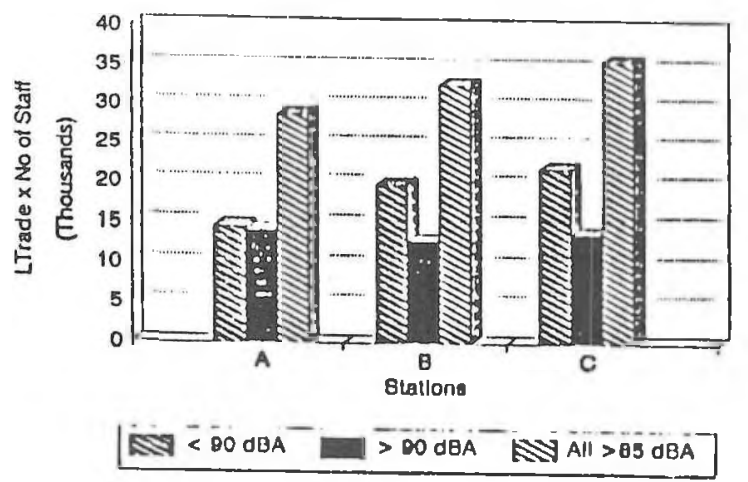

MAXIMUM COLLECTIVE L Trade LTrade $\times$ No of Stall

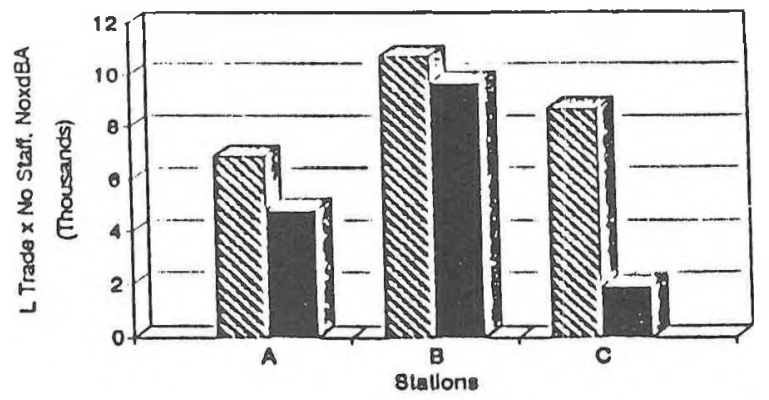

$<80 \mathrm{dBA} \square>0 \mathrm{dBA}$ 